\title{
Managing Customer Relationship through Firm's Market Orientation for Marketing Effectiveness of Banks in Port Harcourt
}

\author{
Sylva Ezema Kalu ${ }^{1}$, Bright ZorBari-Nwitambu ${ }^{2}$ \\ ${ }^{1}$ Marketing department university of Port Harcourt, Port Harcourt \\ ${ }^{2}$ Library department, Ken Saro-Wiwa Polytechnic, Bori
}

*Corresponding Author: Bright ZorBari-Nwitambu, Library department, Ken Saro-Wiwa Polytechnic, Bori

\begin{abstract}
In this study, relevant literature were empirically reviewed with a view to determining the moderating influence of firm's market orientation on customer relationship management and marketing effectiveness among banks in Port Harcourt. The study is a descriptive study that involved field survey, thus, 105 copies of structured questionnaire were designed to capture information from top executives of the 21 registered money deposit banks in Port Harcourt. We analysed data using spearman's correlation coefficient and regression analysis with the aid of the SPSS version 20.0 software. In conclusion, it was revealed that a firm's market orientation significantly moderates the influence of customer relationship management on marketing effectiveness in the banking sector. Giving the foregone, the study strongly recommended that banks that want to be on the cutting edge should make the customer the primary focus of their business objectives.
\end{abstract}

Keywords: Relationship marketing, Strategic marketing, Competitive advantage, Banks and banking.

\section{INTRODUCTION}

Corporations that want to achieve consistency must create, maintain and sustain competitive advantage (Porter, 1985). Creating superior value for money is essential to both the company and the consumer. The buyer must perceive that the expected value of the service provision exceeds its performance (Alderson, 1957). A buyer refers to value as the difference between expected benefits of a product, and the cost of acquiring and using the product (Zeithaml, 1988). That is, the perceived benefit should exceed the acquisition and usage costs of the product.

Constantly attending to customers' needs and wants is key to innovation success in the service sector. Innovation in services is more easily and easily copied and more difficult to protect by means of patenting (Tufano, 1992). However, for efficient growth and marketing effectiveness in banking sector there must be a correlation between an organization's market orientation, innovation and business performance in order to enhance customer sustainability (Narver and slater, 1990; Lai, 2003). Successful firms develop superior product capable of satisfying customers' needs and wants, and also have strong marketing knowledge and skills to develop and launch the product (Calantone et.al, 1996).

There should be a general agreement and a vision statement as to the culture / mission of an organization. Questions like: what is our aim? What are we known for? etc., should be at the back of all employees' minds in order not to deviate from the firm's central goal. This general belief will guide the organization towards achieving marketing effectiveness. Also, employee's motivation through award and recognition, and welfare packages will no doubt spur contact staff into working hard to serve customers better thereby affecting the banks' sales in an upturn direction.

\section{THEORETICAL FOUNDATION}

The underpinning of this study is drawn on relationship marketing and strategic marketing. Relationship marketing is a marketing practice in which an organization strives to maintain and enhance mutual relationship with customers and other stakeholders (employees, marketing channel 
members, the general public, etc.) for the sole aim of customer satisfaction at a profit. An organization that practices relationship marketing is one in which the central focus of everyone in the organization revolves around the customer and the satisfaction of customer needs, thus profit maximization becomes secondary. Strategic marketing on the other hand is an aspect of marketing that employs the design of game plans to attract customers and to secure a strategic position in the competitive marketing arena. Strategic marketing deals with policy implementation aimed at gaining competitive advantage in the saturated marketing environment where competitors are constantly mapping out strategies to win customers all to themselves.

\section{REVIEW OF RELEVANT LITERATURE}

Research on the banking sector has assumed more popularity among scholars in finance and marketing disciplines in recent times. Modern day banking has been increasingly challenging as customers are more aware of what they want and how they want it, and do not want any less of their high expectations from service providers. This explains why a customer can own several accounts with different banks but prefer to do the bulk of his transaction in a particular bank. There's no magic, the truth is he has assessed and weighed the orientation of these banks towards serving their customers and has decided to choose the bank that best satisfy his needs.

After the merger and acquisition policy introduced by the central bank of Nigeria (CBN) under the leadership of Arc. Sanusi, the few banks that could stand the test of time are daily mapping out strategies that will keep profitable customers and also attract new ones, knowing fully well that it is no longer business as usual. Proactive banks are involved the practice of strategic marketing aimed at ousting out competitors and serving customers better to stop them from switching brands. These banks have adopted a firm's market orientation that sees the customers as the reason for their existence and cannot afford to neglect the customers to the preying hands of competitors knowing the consequences it will pose on the bank's fortune.

Technology such as the media and online platform has made today's bank customers so informed and educated that they daily surf the internet in search of banks offering differential services and trendy and savvy bankers are taking advantage of this by designing customer-orientedpolicies that will keep customers glued with the banks for life. They are employing technologies like the automated teller machine (ATM), POS, etc. to reduce long queue in the banking hall.

Interestingly, customers can now at the comfort of their homes do their bank transactions, bank on the go with mobile banking and online banking, use feedback mechanisms and receive instant reply. All these are aimed at serving the customers better. Customer care personnel are readily available to provide answers to questions from customers because failure to do this will expose the customer to seeking out other banks willing to proffer solutions to their numerous banking needs.

Customer relationship management has made banks realize that the key to sustaining and maintaining long term customer patronage and loyalty lies in the ability of banks to maintain cordial relationship with preferred customers. The customer is a firm's greatest asset and sole means of survival, therefore the greatest weapon for fighting and winning the war of competition is nurturing customers' relationship, satisfying them and turning them into partners and advocates in business by spreading positive testimonies that will attract potential customers to the organization (ZorBari-Nwiatambu, 2017). Studies have shown that banks that can harness the power of positive word of mouth will not have difficulties getting the company's message to customers; they constantly strive to satisfy their customers who in turn embark on unpaid word of mouth advertisement for the firm.

\subsection{Marketing Effectiveness}

The most simplified definition of effectiveness is given by Peter Drucker in his book, the effective executive where he defined effectiveness as doing the right things. He equally defined efficiency as doing things right. One must be conscious of the use of both words. Efficiency and effectiveness work together for the smooth running of an organization. Efficiency entails doing things right at the right time while efficiency entails doing things with minimal wastage and at the least possible cost. Marketing effectiveness is the ability of a firm to optimize its market resource with the aim of attaining better results both in the short-run and long-run (Nwokah and Ondukwu, 2009). 
In marketing much priority is placed on effectiveness than efficiency. This is because improving on efficiency does not necessarily imply that you are doing what is right at the time. Effectiveness is more tasking than efficiency (i.e. doing the right thing requires more strategic thinking compared to doing things right). For instance, time is a scarce resource that a proactive marketer cannot afford to waste; therefore performing a task at the right time will minimize cost and at the same time encompass efficiency. Effectiveness is satisfaction-driven while efficiency is more of profit-driven. An organization that concentrates on getting it right at a reduced cost might end up cutting corners and not satisfy its customers thereby loose them to those corporations that are willing to do the right thing (being customer centric). Companies that possess high level of marketing effectiveness will achieve corporate performance more than those firms that do not (Ranchhod, Zhou and Tinson, 2001).

Marketing effectiveness simply put is the performance of the marketing tasks or functions in the right way and at the right time. This has to do with achieving the marketing objectives at the right time and in the right measure. Effectiveness in marketing can be measured using the following indices: customer satisfaction, increased sales volume, corporate image, profitability, market share, good employee-business relations, etc.

\subsection{Firm's Market Orientation}

Firm's market orientation refers to the general belief, focus or mind-setof an organization as regards the customers, employees and competitors. It refers to the organization's culture, reflecting specific set of values (Lado and Maydeu-Olivares, 2001). A firm's market orientation can be focused towards customers, competitors and/ or inter-functional co-ordination (Narver and Slater, 1990). Depending on organizational goal, size and strength, a firm may decide to focus on one or adopt all strategies to suit its purpose.

\subsubsection{Customer-Focused}

An organization that is customer-oriented makes customer satisfaction the core of its business policies. Customer orientation is a business policy whereby all organization's personnel focus on helping customers to meet their long-term needs and wants. Marketing's efforts is centred on searching for possible ways to improving upon firms' competitiveness by seeing the customers as the main essence of being and remaining in business (Smith, 2012).

Customers should not be seen as an object of exploitation, rather a firm should have the belief that long-run profit is earned through customer satisfaction (Ogbuji and ZorBari-Nwitambu, 2017).Customer focused policies will lead to marketing effectiveness if all hand would be on deck towards projecting and upholding the interest of the customers, putting them first in all that the organization does.Today's savvy marketers agree with the notion that their firms should focus on growing mutually beneficial long-term relationship with customers knowing vividly well that their successes revolve around the customers (Singh and Koshy, 2008).

\subsubsection{Competitor-Focused}

Being competitor focused means watching out for the next thing competitors are up to. A firm may be Proactive (i.e. being innovative and setting the pace for others to follow) or Reactive (waiting for competitors to strike and then attack) in its approach to competition. Proactive firms are trend setters while reactive companies are trend follower. Porter (2008) opined that profitability and competitive advantage of a firm within an industry is determined through competition and that competition is the core level of strategy. Porter (1985) identified two main types of competitive advantage: Cost advantage and Differentiation advantage.

A firm is said to have a competitive cost advantage when it is able to deliver the same benefits as competitors but at a lower cost. On the other hand, a firm has differentiation advantage when it is able to deliver benefits that exceed those of competing products (Porter, 1985). Thus, a competitive advantage enables the firm to create superior value for its customers and superior profits for itself. Cost and differentiation advantages are known as positional advantages since they describe the firm's position in the industry as a leader in terms of either cost or differentiation (Porter, 1985).

\subsubsection{Inter-Functional Co-Ordination}

In this scenario all department in an organization are expected to integrate and pursue a common goal of customer satisfaction (Jones 2003; Kohli and Jaworski, 1990; Siguaw, Brown, and Widing 1994; 
Dursun and Kilic, 2011). A market orientation will only be effective when all bank staff work with the marketing department to pursue the sole aim of customer satisfaction, which implies that marketing problem should not be left alone for the marketing department to shoulder, rather it should be the concern of the entire organisation (all hand should be on deck). Lings and Greenley, (2009) is of the opinion that motivated front line employees are likely to become more committed towards the firm's market orientation. Many researchers have viewed that the extent to which a firm thrive depends solely on its ability to create value of its products/services.

Deshpande and Webster (1989) state that firm's market orientation is the most effective and efficient sustainable value creation that enhances superiority in product/service provision or delivery. Atuahene-Gima (1996) states that market orientation is an important determinant of innovation in the service sector like banking industry, thus, innovation success depends on the firm's market orientation, especially on its customer orientation.

Firm's market orientation moderates between customer-oriented strategies and corporate performance of an organization. This further buttress that the success of a firm lies upon the sustainability of the market. In consonance with the assertion of Kohli and Jaworski (1990), there is a positive relationship between a firm's market orientation level and customer satisfaction.

A good market orientation suggests that a firm's market orientation should lead to greater employee commitment to the organization, enhanced customer satisfaction, and increased business profitability (Jaworski and Kohli, 1993 in Jones, 2003). Harrison-Walker (2001) found out that there is a positive relationship between firm's market orientation and customer retention, customer willingness to pay a price premium for the firm's product/ service, customer likelihood to spread positive word-of- mouth communication and customer propensity to not switch brands/service providers. All these variables are widely used measures of the customer loyalty concept which gives rise to customer retention and marketing effectiveness (Jacoby and Chestnut, 1978; Odin et al, 2001; Dick and Basu, 1994).

Key players in the banking industry are beginning to acknowledge the fact that customer relationship management is not just a business policy but a tradition; and that the orientation and impression created among employees and customers will make or mar effective marketing effectiveness in the banking sector.

However, it has been keenly observed that most banks in Port Harcourt have not availed themselves the power of customer relationship management and do not seem to be aware of the effect it poses on marketing effectiveness of banks. This could be that these banks have not properly mapped out their market orientation, and do not maintain a culture whereby every unit of the organization will be conscious of the firm's market orientation in the discharge of their duties. They are still living in the mirage that acquired customers will stick with banks forever no matter the services provided.

Giving this uncertainty, the present study tends to investigate the relationship between customer relationship management and marketing effectiveness, and how this relationship can be moderated by a firm's market orientation using banks in Port Harcourt as a case study.

\section{Point of Departure}

Most authors have argued that customer relationship management has a relationship with marketing effectiveness. However, the present study tends not only to look at a direct relationship between the said variables but also take into account the moderating relationship that exists between them.

This is because customer relationship management as a policy can be marred if not backed by the orientation of a firm. Firm's market orientation is the mind-set of an organization towards attaining set goals. That is to say, the policy may be favourable but if the mind-set/ orientation of the organization or orientation of the executors of such policy is not in line with the central intent of the policy, there would be a synergy crisis among stakeholders (management, customers, employees, etc.) of the organization.

\section{Methodology}

This study is a descriptive study involving correlational research design with emphasis on the moderating influence of firms' marketing orientation on the relationship between the predictor and criterion variables. We used the questionnaire to gather relevant data from 105 respondents of the 21 
deposit money banks in Port Harcourt. Hypotheses were tested with spearman rank correlation coefficient and partial correlation analysis to ascertain the correlation and moderating relationship among studied variables. Reliability of instrument was tested using chronbach alpha at a bench mark of 0.7 .

The study variables are:

- Predictor variable: Customer relationship management

- Criterion variable: Marketing effectiveness

- Moderating variable: Firm's market orientation

\section{ANALYSIS AND DISCUSSION OF FINDINGS}

The current study was conducted on top cadre managers in the 21 deposit money banks in Port Harcourt and a total of 105 copies of questionnaire were distributed, out of which 93 with $88.6 \%$ response rate were retrieved and useful while 12 copies (11.4\%) were either not retrieved or contained errors and were discarded.

The spearman's rank correlation coefficient $\left(\mathrm{rh}^{2}\right)$ was used to ascertain the nature of relationship among variables, and also, the partial correlation was conducted to know the moderating effect on the dependent and independent variables.

\subsection{Influence of Customer Relationship Management on Marketing Effectiveness}

Here we looked at the influence the independent variable - customer relationship management poses on the criterion variable - marketing effectiveness. Table 6.1 below is summary of regression analysis showing the effect of the relationship among variables.

Table6.1. Summary of Regression Analysis result showing the Influence of customer relationship management (CRM) on marketing effectiveness (ME)

\begin{tabular}{|l|c|c|c|c|c|c|c|c|c|}
\hline Variables & Coef. & t-cal & sig. t & t-tab $(0.05,92)$ & $\mathrm{R}$ & $\mathrm{R}^{2}$ & F-cal & F-tab $(0.05,1,92)$ & sig $\mathrm{f}$ \\
\cline { 1 - 4 } Constant & 0.276 & 1.056 & 0.294 & \multirow{2}{*}{1.96} & 0.813 & 0.662 & 177.9 & 3.92 & \multirow{2}{*}{0.000} \\
\hline CRM & 0.907 & 13.34 & 0.000 & & & & & & \\
\hline
\end{tabular}

Dependent Variable; Marketing effectiveness

Source: SPSS 20.0 Output (based on field survey data 2017)

$\mathrm{ME}=\mathrm{ao}+\mathrm{a} 1 \mathrm{CRM}+\mathrm{U} 1$

$\mathrm{ME}=0.276+0.907 \mathrm{CRM}$

T-values $=(1.056)(1.709)$

Table 6.1 above shows that the correlation coefficient is 0.813 . This implies that a very strong correlation exist between the predictor variable and the dependent variable at $81.3 \%$. The Coefficient of Determination $\left(\mathrm{R}^{2}\right)=0.662$. It implies that $66.2 \%$ variation in marketing effectiveness is explained by variations in Customer relationship management. This is an indication that the model has a good fit. The remaining $33.8 \%$ is explained by other variables not included in the model. Also, the coefficient of variation 0.907 (very close to 1 ) shows a strong association between variables. The Fcalculated of 177.9 had a corresponding significant f-value of 0.000 ; the researcher therefore concludes a good model utility. Conventionally F-Cal $=177.9>$ F-tab $_{(0.05,1,92)}=3.92$ hence the decision of a good model utility upheld.

\subsection{Moderating Effects of Firm's Market Orientation on the Influence of Customer Relationship Management (CRM) on Marketing Effectiveness (ME)}

Here we had a look at how firm's market orientation moderates the influence of customer relationship management on marketing effectiveness in the banking sector in Port Harcourt. 
Managing Customer Relationship through Firm's Market Orientation for Marketing Effectiveness of Banks in Port Harcourt

Table6.2. Summary of partial correlation analysis result showing how firm market orientation is moderates the Influence of customer relationship management (CRM) on marketing effectiveness (ME)

\begin{tabular}{|c|c|c|c|c|c|}
\hline \multicolumn{6}{|c|}{ Correlations } \\
\hline $\begin{array}{l}\text { Control } \\
\text { Variables }\end{array}$ & Variables & Statistics & $\begin{array}{l}\text { Customer relation } \\
\text { Ship management }\end{array}$ & $\begin{array}{l}\text { Marketing } \\
\text { effectiveness }\end{array}$ & $\begin{array}{l}\text { Firm's Market } \\
\text { orientation }\end{array}$ \\
\hline \multirow[t]{9}{*}{ None $^{2}$} & \multirow{3}{*}{$\begin{array}{l}\text { Customer } \\
\text { relationship } \\
\text { management }\end{array}$} & Correlation & 1.000 & .813 & .634 \\
\hline & & Significance (2-tailed) & . & .000 & .000 \\
\hline & & df & 0 & 91 & 91 \\
\hline & \multirow{3}{*}{$\begin{array}{l}\text { Marketing } \\
\text { effectiveness }\end{array}$} & Correlation & .813 & 1.000 & .823 \\
\hline & & Significance (2-tailed) & .000 & 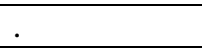 & .000 \\
\hline & & df & 91 & 0 & 91 \\
\hline & \multirow{3}{*}{$\begin{array}{l}\text { Firm's } \\
\text { Market } \\
\text { Orientation }\end{array}$} & Correlation & .634 & .823 & 1.000 \\
\hline & & Significance (2-tailed) & .000 & .000 & . \\
\hline & & $\mathrm{df}$ & 91 & 91 & 0 \\
\hline \multirow{6}{*}{$\begin{array}{l}\text { Market } \\
\text { Orientation }\end{array}$} & \multirow{3}{*}{$\begin{array}{l}\text { Customer } \\
\text { relationship } \\
\text { management }\end{array}$} & Correlation & 1.000 & .701 & \\
\hline & & Significance (2-tailed) & . & .000 & \\
\hline & & df & 0 & 90 & \\
\hline & \multirow{3}{*}{$\begin{array}{l}\text { Marketing } \\
\text { effectiveness }\end{array}$} & Correlation & .701 & 1.000 & \\
\hline & & Significance (2-tailed) & .000 & . & \\
\hline & & $\mathrm{df}$ & 90 & 0 & \\
\hline
\end{tabular}

a. Cells contain zero-order (Pearson) correlations.

\subsection{Decision Rule for Partial Correlation}

If the difference between the Zero Order Partial Correlation (ZPC) and the Controlled Partial Correlation $(C P C)>0.01$, conclude a significant moderating influence; otherwise reject significant moderating influence.

Zero Order Partial Correlation $(\mathrm{ZPC})=0.813$, Controlled Partial Correlation $(\mathrm{CPC})=0.701$. The difference between the Zero Order Partial Correlation (ZPC) and the Controlled Partial Correlation (CPC) $(0.813-0.701)=0.112>0.01$ hence the study concludes that firm's market orientation significantly moderate the effect of customer relationship management on marketing effectiveness.

The positive sign of the difference is an indication that Firm's Market Orientation asserts a positive moderating influence on the relationship between customer relationship management and marketing effectiveness in the banking sector in Port Harcourt.

\section{CONCLuSiON}

Giving the foregone, we draw the following conclusions:

1. There is a significant positive relationship between customer relationship management and marketing effectiveness in the banking sector in Port Harcourt.

2. Firm's market orientation significantly moderates the relationship between customer relationship management and marketing effectiveness in the banking sector in Port Harcourt.

\section{STUDY IMPLICATIONS}

\subsection{Theoretical Implication}

Marketing effectiveness (ME) is a function of Customer relationship management (CRM) and is moderated by Firm's market orientation (FMO).

The model is represented as:

$\mathrm{ME}=f(\mathrm{CRM})^{F M O}$

\subsection{Practical Implications}

1. Customer relationship management will lead to marketing effectiveness when the firm's market orientation is defined and all organization's staff key into such orientation.

2. Organizations that wish to achieve marketing effectiveness should maintain mutual relationship with preferred customers and inculcate this virtue/ culture into all contact staff.

3. Employees will project and promote a firm's market orientation only when they are adequately motivated on the job. 


\section{RECOMMENDATIONS}

1. Banks in Port Harcourt should have a defined market orientation which would serve as a road map for the company's mission and vision.

2. Banks that want to achieve marketing effectiveness should adopt and practice a customer-focused market orientation in their customer relationship management approach as this is key to attaining and maintaining greater heights in today's competitive banking arena.

3. There should be inter-functional coordination among all staff geared towards serving/ satisfying customers' needs (i.e. all hand should be on deck towards acquiring and retaining the firm's greatest asset - customers).

\section{Contribution to KnOWLEDGe}

Other studies have examined a parallel relationship between customer relation management and marketing effectiveness. In this study however, we sought to establish a moderating relationship between studied variables.

Hence, we state here that the study's immense contribution to knowledge is embedded in seeking to ascertain the moderating effect of firm's market orientation on customer relationship management and marketing effectiveness in the banking industry in Port Harcourt.

Also, the theoretical and heuristic model of the study has contributed immensely to marketing literature.

\section{SUgGESTION FOR FURTHER STUDIES}

The present study examined the relationship between customer relationship management and marketing effectiveness and the moderating effect of firm's market orientation on this relationship. We suggest that further studies be carried out in other industries, and in other geo-political zones in Nigeria.

\section{REFERENCES}

[1] Alderson, W. (1957).Marketing behavior and executive action. Homewood: Richard D. Irwin, Inc.

[2] Atuahene- Gima, K. (1996). Market orientation and innovation. Journal of business Research, 35, 93-103.

[3] Calanton, R.J. et al (1996). Controllable factors of new products success: A cross-national comparison. Marketing science, 15(4), 341-58.

[4] Deshpande, R. \& Webster, F.E. (1989). Organization culture and marketing: Defining the research agenda. Journal of Marketing: 53 (January), 3-15.

[5] Dick, A.S. \&Basu, K. (1994). Customer loyalty: Toward an integrated conceptual frame-work. Journal of the academy of marketing science, 22(2), 99-113.

[6] Dursun, T. \& Kilic, C. (2011).Exploring occupational and strategic drivers of individual customer orientation. Journal of Business \& Economics Research,9 (5).

[7] Harrison-walker, L.J. (2001). The measurement of a market orientation and its impact on business performance. Journal of quality management, 6(2), 139-72.

[8] Jacoby, J. and chestnut, R.W. (1978).Brand loyalty: Measurement and management. New York: Wiley. 53-70

[9] Jones, E. (2003). Firm market orientation and salesperson customer orientation: Interpersonal and intrapersonal influences on customer service and retention in business-to-business buyer-seller relationships. Journal of Business Research 56, 323-340.

[10] Kohli, A.K. \& Jaworski, B.J. (1990). Market orientation: The construct, research propositions, and managerial implications. Journal of marketing, 54, 1-18.

[11] Lado, N. \& Maydeu-Olivares, A. (2001).Exploring the link between market orientation and innovation in the European and US insurance markets. International marketing review 18(2), 130-144. OMCB University press, 0265-1335.

[12] Lai, K.H. (2003). Market orientation in quality-orientated organizations and its impact on their performance. International journal of production economics, in press.

[13] Lings, I. \& Greenley, G. (2009).The impact of internal and external market orientations on firm performance. Journal of Strategic Marketing, 17(1), 41-53. Routledge (Taylor \& Francis). 
[14] Narver, J.C. \& Slater, S.F. (1990).The effect of market orientation on business profitability. Journal of marketing, 54 (October), 30-35.

[15] Nwokah, G.N. \& Ondukwu, E. (2009).Competitive intelligence and marketing effectiveness in corporate organizations in Nigeria. African journal of marketing management 1(1), 10-22 April.

[16] Odin, et al (2001). Conceptual and operational aspects of brand loyalty: An empirical investigation. Journal of business research, 53(2), 75-84.

[17] Ogbuji, C.N. \& ZorBari-Nwitambu, B. (2017). Customer service quality and corporate performance in the banking sector in Port Harcourt. GOUNI journal of management and social sciences, 3(1) 109-117. ISSN: 2550-7265.

[18] Porter, M. E. (1985). Competitive advantage. New York: The free press.

[19] Porter, M.E. (2008). On competition. The Harvard business review.

[20] Ranchhod, A., Zhou, F. \& Tinson, J. (2001).Factors influencing marketing effectiveness on the web. Information resources management journal 14(1). DOI: 10.4018/irmj.2001010101

[21] Siguaw, J.A., Brown, G. \& Widing, R.E. (1994).The Influence of the Market Orientation of the Firm on Sales Force Behavior and Attitudes. Journal of Marketing Research 31(1), 106-116. American Marketing Association DOI: $10.2307 / 3151950$

[22] Singh, R. Koshy, A. (2008). Salesperson's customer orientation: A reconceptualization and a new definition. Indian institute of management Ahmedabad, India. Research and Publications (April).

[23] Smith, J.G. (2012). An investigation of market orientation and selected personality traits' relationship with dimensions of customer orientation in salespersons. The Marketing Management Journal, 22(1), 97-112. The Marketing Management Association.

[24] Tufano, P. (1992). Financial innovation and first mover advantages. Journal of applied cooperate finance, 1, 83-87.

[25] Zeithaml, V. A. (1988). Consumer perception of price, quality, and value: A means-end model and synthesis of evidence. Journal of marketing, 52 (July), 2-22.

[26] ZorBari-Nwitambu, B. (2017). Positive word of mouth and Profitability: the experience of banks in Port Harcourt - Nigeria. International journal of managerial studies and research 5(5) May, 42-48. ISSN: 24390349.

\section{AUTHORS' BIOGRAPHY}

Sylva Ezema Kalu, is a professor of marketing and lectures in the University of Port Harcourt, Port Harcourt-Nigeria. He is currently the Director, Institute of International Trade and development, University of Port Harcourt. Sylva Ezema Kalu has several marketing books and journals to his credit. He is happily married and blessed with lovely children.

Bright ZorBari-Nwitambu, is a staff of Ken Saro-Wiwa Polytechnic, Bori -Ogoni in Rivers State, Nigeria. She works in the Library department of the Polytechnic and is currently pursuing a Doctorate degree (Ph.D.) in Marketing at the University of Port Harcourt, Port Harcourt. ZorBari-Nwitambu is a Christian, happily married and blessed with a son.

Citation: Sylva Ezema Kalu, and ZorBari-Nwitambu Bright. "Managing Customer Relationship through Firm's Market Orientation for Marketing Effectiveness of Banks in Port Harcourt." International Journal of Managerial Studies and Research (IJMSR), vol 5, no. 9, 2017, pp. 43-50. doi: http://dx.doi.org/10.20431/ 2349-0349.0509008.

Copyright: () 2017 Authors. This is an open-access article distributed under the terms of the Creative Commons Attribution License, which permits unrestricted use, distribution, and reproduction in any medium, provided the original author and source are credited. 